\title{
OBITUARIES
}

Prof. H. W. Turnbull, F.R.S.

By the death of Prof. Herbert Westren Turnbull at Grasmere on May 4, Britain has lost a distinguished mathematician of the older school, while many mathematicians in England and Scotland have lost a personal friend.

Herbert Turnbull, a son of W. Peveril Turnbull, H.M. inspector of schools, was born in Wolverhampton in 1885. From Sheffield Grammar School he went as a scholar to Trinity College, Cambridge, being Second Wrangler in 1907, first in the first division of Mathematical Tripos II in 1908, and Smith's Prizeman in 1909. After a varied experience of lecturing at Cambridge, Liverpool and Hong Kong, he seemed for a few years to be likely to follow his father's career, teaching as he did at Repton for three years and becoming an H.M. inspector of schools. This pattern was quite altered in 1921 by his appointment to the chair of mathematics in the United College, University of St. Andrews.

The result was to associate his name permanently, and especially to Scottish mathematicians, with St. Andrews. He wrote there the great majority of his sixty or more published papers, and founded a school of algebra and geometry of the older type which, though younger mathematicians have moved to the more modern abstract disciplines, had value in its day. Turnbull was inspired immediately by J. H. Grace and Alfred Young, his associates and seniors by slightly more than a decade at Cambridge, and through them by the Continental masters Clebsch, Gordan and Capelli, with Cayley and Sylvester beyond again. The realm most congenial to him was that of the invariants and covariants of algebraic forms, as investigated by the Clebsch-Aronhold symbolic calculus, of which he became the last and in some ways perhaps the greatest master; but he was constantly aware of the applications to projective geometry. Also, when in 1927 Alfred Young began his new attack on invariants with the Frobenius-Schur group algebra of the symmetric group, Turnbull was fully alive to the new range thus opened, and some of his work consists of a reconciliation of the symbolic with the group-algebraic approach. His name will also be associated with memoirs and text-books on matrices and determinants.

An interest in the history of mathematics first found utterance in a small book, The Great Mathematicians (1929); but the discovery of hitherto unknown documents relating to the work of the Scottish mathematician, James Gregory (1638-75), produced his first historical work on a larger scale, the James Gregory Tercentenary Memorial Volume. Felicitously, this was ready in time for the James Gregory tercentenary celebrations which, somewhat resembling the Napier tercentenary celebrations of 1914, took the form of an international congress of the Edinburgh Mathematical Society-the University of St. Andrews and the Royal Society of Edinburgh being sponsors. This occasion, too soon overshadowed by rumours of war, will be remembered by many as the special one in which Turnbull, in the prime of life and ably seconded by his wife, showed himself as the host of hosts and moreover as an excellent musician, for he was a pianist of almost professional standard. To Scottish mathematicians these qualities were well known, in the annual June meeting of the Edinburgh Mathematical Society at St. Andrews and its four yearly colloquia held there.

Retiring in 1950, Turnbull as emeritus professor devoted himself to his second and major historical work, the editing of the correspondence of Isaac Newton. He lived to see the first volume, handsome and impressive, appear in 1959, and to know that the second was well under way.

His character was founded on the simplest faith, absolute sincerity and the desire to serve. His many friends, in their sympathy extended to his wife and their son Derwent, will remember the man first, and $\begin{array}{ll}\text { then the mathematician. } & \text { A. C. AITKEN }\end{array}$

\section{Prof. C. G. Jung}

Carl Gustav Jung, who died on June 6, was born on July 26, 1875, at Kesswyl, in Switzerland. His father was a clergyman and he was brought up in his parsonage in the country. He attended school at Basle and was educated in medicine in that city, where he graduated.

In 1900 he became assistant in the State Mental Hospital and in the psychiatric clinic of the University of Zurich, later becoming senior staff physician there until 1909.

In 1902 he spent six months in Paris attending $P$. Janet's lectures and worked in Zurich with $\mathrm{E}$. Bleuler. He first met Freud in 1906.

When Freud put forward his ideas and discoveries he had been greeted with scorn and derision until Bleuler made it known that his views were regarded sympathetically by the Zurich school. The interest of the Swiss certainly helped to direct the scientific world towards psychoanalysis, and Freud acknow. ledged his gratitude, stating, "The Zurich doctors made, as it were, the nucleus of the little band which was fighting for the recognition of psychoanalysis. Only in Zurich was there a possible opportunity to learn the new art and to apply it in practice".

Freud at this time wished to take a less prominent place in the Psychoanalytical Society and diplomatically transferred his presidency to Jung.

Jung must have been an impressive young man in those days, and Wittels described him in his wellknown depiction as "Tall and upright of figure, like a young Siegfried". When I first saw him some thirty years ago he was middle-aged, but still well built, with a rather burly figure, a jovial red face, short clipped hair, and gold-rimmed glasses. He was a good lecturer and able to impress an audience with his profundity. With those who sought his views he had a kindly, serious manner and he was certainly 'a good mixer'.

The first important investigation of note which he made was his careful study of association. His research followed on the experimental work started by Galton in 1879 and Wundt a year later. This was 'controlled association' or the timing of words associ- 